\title{
INFLUENCE OF OPTICAL ABERRATIONS OF AN EYE ON RESOLUTION OF DICHOPTIC IMAGES
}

\author{
M. Kuibida ${ }^{1}$, V. Karitāns ${ }^{1,2}$ \\ ${ }^{1}$ Department of Optometry and Vision Science, University of Latvia \\ ${ }^{2}$ Institute of Solid State Physics, University of Latvia \\ 8 Kengaraga Str., Rīga, LV-1063, LATVIA
}

\begin{abstract}
A human eye suffers from optical distortions or aberrations classified into lower-order aberrations and higher-order aberrations. The influence of higher-order aberrations on the visual perception has been much investigated. In our study, we paid attention to the influence of interocular differences between the degrees of different type aberrations on the ability to resolve dichoptic images. We investigated four types of aberrations - astigmatism, coma, trefoil, and spherical aberration. The lowest threshold was observed for the trefoil aberration, whereas the highest - for spherical aberration. Thus we have concluded that the thresholds of interocular differences between the degrees of higher-order aberrations needed to resolve dichoptic images strongly depend on the symmetry and orientation of the wavefront map and also on the aberrations to which the observer has adapted throughout the life.
\end{abstract}

\section{INTRODUCTION}

It is well known that a human eye is not a perfect optical system but suffers from numerous aberrations classified into lower-order aberrations (LOAs) and higher-order aberrations (HOAs). The higher the order of aberration, the more complex is its nature. The LOA and the lowest HOA are those affecting the most an eye's optical quality. Mathematical description of aberrations is most frequently given by the Zernike polynomials, each polynomial corresponding to a particular type of aberration. The parameter commonly used to describe the amount of aberrations is the root-mean-square (RMS) of the wavefront of aberration. A LOA can be corrected by glasses and contact lenses, while a HOA - only by adaptive optics. Shortly, the basic principle behind the correction of aberrations by adaptive optics is manipulation with the phase of the wavefront. Not only LOAs but also HOAs affect the visual performance and reduce resolution of retinal images. The visual functions affected by HOA are: visual acuity, contrast sensitivity, stereo vision, accommodation, etc. Even a 6-fold improvement in the contrast sensitivity has been reported for corrected HOA [1]. Yoon et al. [2] also measured the contrast sensitivity after correcting the monochromatic and chromatic aberrations. They found that after correcting HOA the contrast sensitivity thresholds were several times lower, especially at higher spatial frequencies. Marcos et al. [3] investigated dependence of the visual acuity on the luminance and contrast polarity when HOAs were corrected. These authors found that for the black-on-white contrast letters the 
visual acuity improved at all luminance levels when HOA were corrected, whereas for the opposite polarity the HOA reduced acuity only at low and moderate luminance levels.

Interocular differences of RMS value of HOA are known to influence also the stereo threshold as noted in work [4] whose authors found that by increasing these differences the maximum stereo disparity perceivable by the observer is strongly reduced.

The purpose of our study was to find the threshold of interocular difference between the RMS values of different type aberrations so that the images presented separately to each eye can be resolved from each other. Two images, each of them shown to only one eye, are said to be dichoptic. As far as we know, no studies have examined this issue.

\section{EXPERIMENTAL}

\subsection{Observers}

In the study, 15 healthy observers (all females) took part. Each of them was introduced to the aim of the study. No observers complained of any disorders of the eyes or the visual system.

\subsection{Optical layout}

The experimental setup used in our study is shown schematically in Fig. 1. A separate stimulus was shown to each eye through a telescopic system. The telescopic systems were required to ensure that the whole surface of the deformable mirror (DM) was used to generate aberrations. The optical power of lenses com-

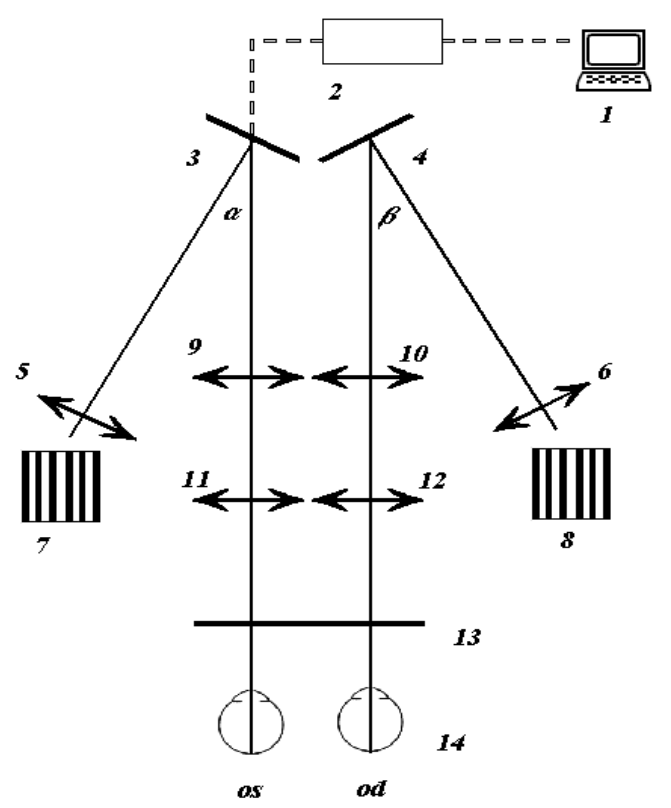

Fig. 1. Optical layout for measuring the threshold difference of interocular RMS of HOA for dichoptic images to be resolved: 1 - computer controlling the DM; 2 - DM control unit; 3 -DM; 4 - plane mirror; 5, 6-aspheric lenses; 7, 8-stimuli; 9-12-lenses of telescopic systems; 13 - opaque screen containing pinholes; 14 - observer's eyes. 
prising the telescopic systems was: $\mathrm{L}_{9}=+5.5 \mathrm{D} ; \mathrm{L}_{10}=+7.75 \mathrm{D} ; \mathrm{L}_{11}=+33.25 \mathrm{D}$; $\mathrm{L}_{12}=+50 \mathrm{D}$. The difference between magnifications of the telescopic systems was about $6.6 \%$. The DM (provided by the Russian corporation Visionica) has 19 independent segments, which can be moved back and forth to change the shape of DM surface. The dichoptic image presented to the right eye served as a reference stimulus, while that presented to the left eye - as a comparison stimulus and was distorted by different kinds of aberrations using the DM. The stimuli were placed in focus of the aspheric lenses (optical power $\mathrm{F}=+4 \mathrm{D}, \varnothing=36 \mathrm{~mm}$ ) to reduce the effects of spherical aberration as much as possible. An opaque screen with pinholes was used to separate the fields of view of both eyes.

\subsection{Calibration}

The RMS values of wavefronts were measured at voltages from 0 to $\mathrm{V}_{\max }$ in steps of $\mathrm{V}_{\max } / 10$, where $\mathrm{V}_{\max }$ was $-300 \mathrm{~V}$ or $+300 \mathrm{~V}$. The measurements were made using a Shack-Hartmann wavefront sensor (model SHAH-0620, also provided by Visionica). For calibration a He-Ne laser at $\lambda=633 \mathrm{~nm}$ was used.

\subsection{Psychophysical method}

To find the threshold of interocular difference between the RMSs of aberrations needed to resolve the dichoptic images the method of constant stimuli (illustrated by Fig. 2) was applied. At time t1 both the left eye (LE) and the right eye (RE) saw identical images. Such dicoptic images, when fused by brain, result in perception of a single image called the reference image. At time t 2 the image seen by the left eye was not changed, whereas that seen by the right eye was distorted by some aberration. Thus, at time $\mathrm{t} 2$ both dichoptic images were fused into a single image called the comparison image. The observer had to give the answer whether or not she/he has noticed any difference between the reference and the comparison image. If the observer noticed differences, value 1 was recorded, and 0 if otherwise.

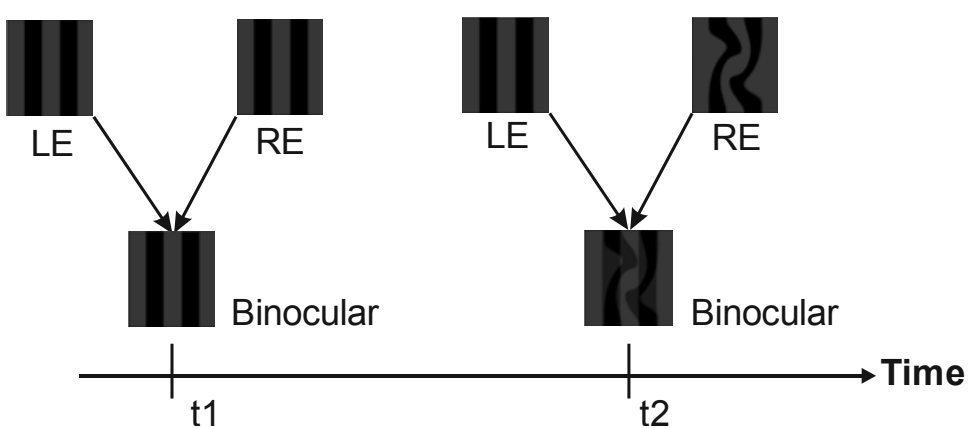

Fig. 2. Sequence of presenting stimuli.

At time $\mathrm{t} 1$ both the LE and the RE saw identical stimuli, and the binocular image did not differ from any of the monocular images. At time $\mathrm{t} 2$ the image of the RE was distorted by a definite type aberration which resulted also in distorted binocular perception. Both stimuli were demonstrated to the observer with time delay $\sim 100 \mathrm{~ms}$. The light-shaded areas in binocularly perceived image at $\mathrm{t} 2$ are given for clarity, with the real filling colour remaining black. 
Altogether, 11 levels of aberration were assumed; during the experiment, aberration of each level was used 10 times to distort the comparison stimulus.

\subsection{Data analysis}

Psychometric functions were measured based on the acquired data, and the thresholds have been found for the interocular differences between RMSs of aberrations. In Fig. 3, a sample psychometric function is shown. The number of 'Yes' responses on the $y$-axis indicates how many times (out of 10) the subject reported a difference between the reference and the comparison stimuli at a definite amount of aberration. On the $x$-axis the percentage of maximum RMSs is given. The threshold was taken as the RMS at which the psychometric function assumes value 5. The thresholds were found both at positive and negative voltages applied to the DM. The statistical significance of the difference between thresholds was determined using Student's t-test.

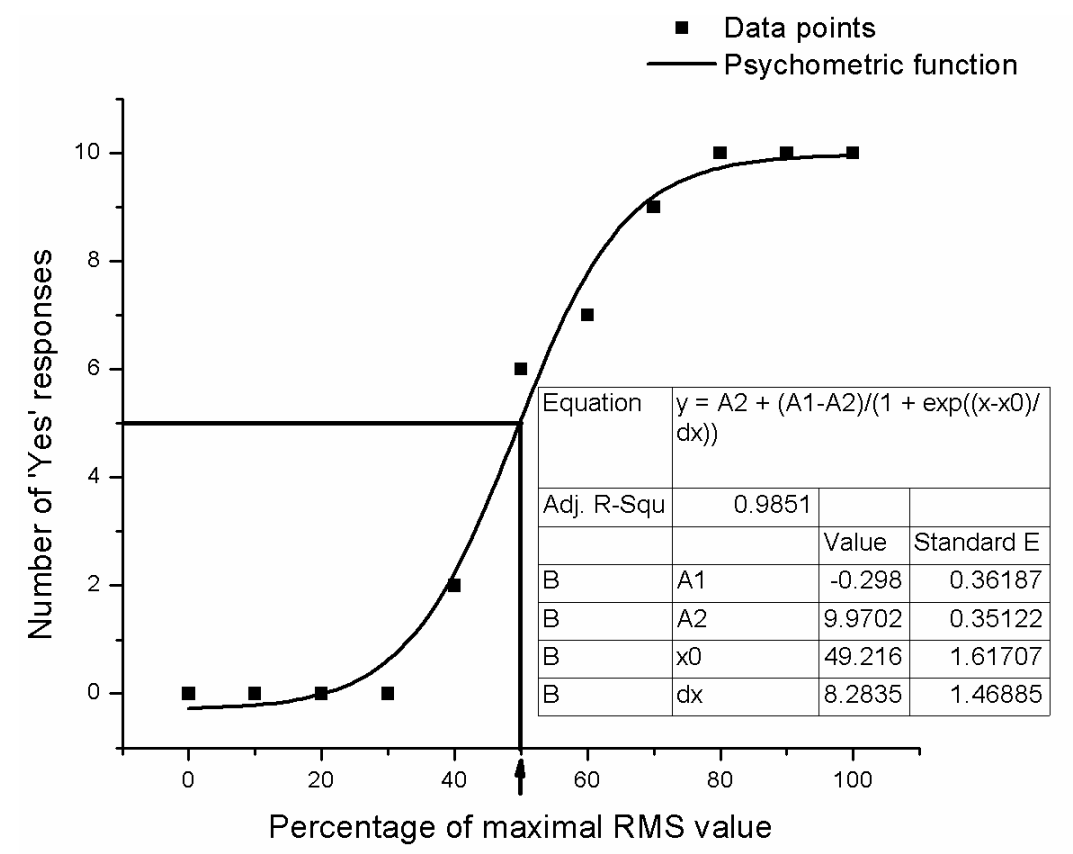

Fig. 3. A sample psychometric curve relating an observer's response to deformation of the wavefront. Threshold was taken as RMS of the wavefront at which psychometric function had value 0.5 . The black arrow indicates the threshold value of interocular RMS differences (expressed in percentage of the maximum RMS).

\section{RESULTS}

\subsection{Wavefront generation}

In Fig. 4, the wavefront and the interferogram for each type of aberration are shown in polar coordinates within a unit circle. The maximum RMS for each type of aberration is: for astigmatism $\mathrm{RMS}_{\text {ast(max })}=0.56 \mu \mathrm{m}, \mathrm{RMS}_{\text {coma(max) }}=0.43 \mu \mathrm{m}$, $\mathrm{RMS}_{\text {trefoil(max) }}=0.23 \mu \mathrm{m}, \mathrm{RMS}_{\text {spher(max })}=0.70 \mu \mathrm{m}$. The wavefront deformation at each point can be determined from the colour scale. 

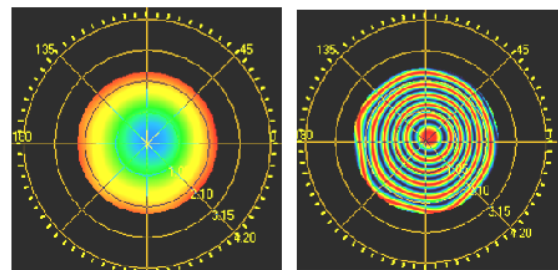

a
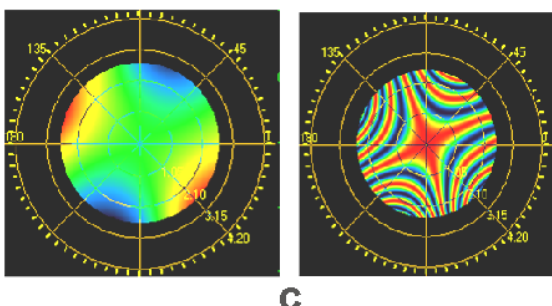
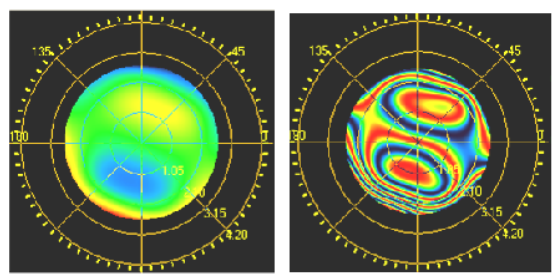

b

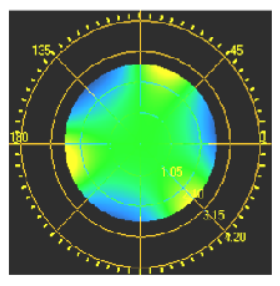

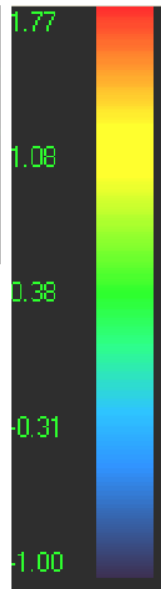

Fig. 4. The wavefront and the interferogram of each aberration: $a$-spherical aberration, $b$ - coma, $c$ - astigmatism, $d$ - trefoil aberration. The colour bar to the right allows determination of the wavefront deviation $(\mu \mathrm{m})$ from a plane wavefront.

\subsection{Threshold values}

The Student t-test revealed no significant difference between the mean threshold values determined in the case when positive and negative voltages were applied in turn to the DM ( $p>>0.05)$. This was true for all types of aberrations. Since the mean threshold values did not differ significantly at positive or negative voltage applied to the DM, the threshold averaged for the two measurements was taken as its final value. The threshold of interocular differences between RMSs of wavefront aberrations was the highest in the case of spherical aberration and the lowest for the trefoil aberration. Thresholds for all types of aberrations tested are summarized in Table 1.

Table 1

Thresholds of interocular difference between RMSs of different types of aberrations for resolving dichoptic images

\begin{tabular}{|c|c|}
\hline Type of aberration & Threshold, $\boldsymbol{\mu m}$ \\
\hline Astigmatism & $0.154 \pm 0.01$ \\
\hline Spherical aberration & $0.204 \pm 0.014$ \\
\hline Coma & $0.126 \pm 0.008$ \\
\hline Trefoil & $0.105 \pm 0.007$ \\
\hline
\end{tabular}

\section{DISCUSSION}

It seems apparent from our results that the difference thresholds may be affected differently by various types of aberrations. We suppose that the way in which the difference thresholds are changed (elevated or lowered) is strongly dependent on the wavefront symmetry. The cornea preserves an approximately spherical shape throughout the life, which is the reason why many eye models developed starting from Gullstrand's eye model assume the cornea to be a sphere. 
From the infant's age on, a person begins to adapt to this type of aberration. Besides, at the very early stages of life the brain is very plastic and susceptible to the influences of environment. Among different types of information dictating the development of brain during childhood the visual information is also found. As a person at the adult age has adapted to spherical aberration, a relatively high difference threshold is required so that differences between dichoptic images can be noticed.

We should also make allowance for the size difference (i.e. the difference in size between the retinal images of eyes called aniseikonia) due to unequal magnifications of the telescopic systems. It is known from literature (see, e.g. [5]) that the upper limit of aniseikonia which an observer can tolerate is about $9 \%$. In our study, the difference was about $6.6 \%$; we therefore are of the opinion that the differences noticed by the observer could not arise because of the size differences between two images.

Other (less common) higher-order aberrations may arise from eye pathologies (such as pathologies of lids, keratoconus, and others).

The results obtained may also be helpful in designing the progressive power lenses (PPL) prescribed for the patients who need presbiopic correction (the presbyopia - a refractive state of the optical system of an eye when the lens is unable to accommodate for near vision). The PPL have very complicated surface structure, and this complexity results in different aberrations across such a surface. Often both eyes look through the sections of PPL that introduce different types and amount of aberrations. Often people find it difficult to get accustomed to PPL lenses due to aberrations. Keeping the interocular difference of aberrations below the levels found in our experiments may help avoid these undesirable side-effects of wearing PPL.

An interesting study addressing this issue has been carried out by Tahir et al. [6]. These authors found that there are notches in the contrast sensitivity function that correlate with the orientation of the aberration map. This finding supports still further the evidence that this orientation may be important for visual perception.

\section{CONCLUSIONS}

The optical scheme constructed in the experiment is useful for generation of wavefront aberrations. The results may indicate that an observer is less sensitive to aberrations to which she/he has adapted. The threshold measurements may also be useful when designing PPL that would allow reducing the amount of many aberrations caused by their complex surface shape.

\section{ACKNOWLEDGEMENT}

The research was supported by the ESF project "Support of Doctoral Studies at the University of Latvia" (project No. 2009/0138/1DP/1.1.2.1.2/09/IPIA/VIAA/004).

The authors would also like to thank professor Maris Ozolins for practical help and advice. 


\title{
REFERENCES
}

1. Liang, J., Williams, D.R., \& Miller, D.T. (1997). Supernormal vision and highresolution retinal imaging through adaptive optics. Journal of the Optical Society of America, A 14 (11), 2884-2892. DOI: 10.1364/JOSAA.14.002884.

2. Yoon, G.Y., \& Williams, D.R. (2002). Visual performance after correcting the monochromatic and chromatic aberrations of the eye. Journal of the Optical Society of America, A 19 (2), 266-275.

3. Marcos, S., Sawides, L., Gambra, E., \& Dorronsoro, C. (2008). Influence of adaptiveoptics ocular aberration correction on visual acuity at different luminances and contrast polarities. Journal of Vision, 8 (13), 1-12. DOI: 10.1167/8.13.1.

4. Jiménez, J.R., Castro, J., Salas, C., Jiménez, R., \& Anera, R. (2007). Effect of interocular differences in higher-order aberrations on binocular visual performance. Perception Abstract Supplement, 36, 68.

5. Crone, R.A., \& Leuridan, O.M. (1973). Tolerance for aniseikonia. II. Determination based on the amplitude of cyclofusion. Albrecht von Graefes Archiv fur klinische und experimentelle Ophthalmologie, 188 (1), 17-22. DOI: 10.1007/BF00410861.

6. Tahir, H.J., Parry, N.R.A., Pallikaris, A., \& Murray, I.J. (2009). Higher-order aberrations produce orientation-specific notches in the defocused contrast sensitivity function. Journal of Vision, 9 (7), 1-12. DOI: 10.1167/9.7.11.

\section{ACS OPTISKO ABERĀCIJU IETEKME UZ DIHOPTISKU ATTĒLU ATŠĶIRŠANAS SPĒJU}

\author{
M. Kuibida,V. Karitāns, \\ Kopsavilkums
}

Cilvēka acij piemīt optiskie traucējumi jeb aberācijas, kas tiek klasificētas zemāko un augstāko kārtu aberācijās. Augstāko kārtu aberāciju ietekme uz redzes uztveri ir l̦oti plaši pētīta. Šajā pētījumā mēs pievērsām uzmanību tam, kā dažādu aberāciju apjoma atšķirīiba starp acīm ietekmē dihoptisku attēlu atšķiršanas spēju. Mēs pētījām astigmātisma, komas, trīslapiņu un sfēriskās aberācijas ietekmi uz dihoptisku attēlu atšķiršanas spēju. Zemākais slieksnis tika novērots trīslapiṇu aberācijas gadījumā, turpretim augstākais slieksnis bija novērojams sfēriskās aberācijas gadījumā. Mēs secinājām, ka dihoptiskus attēlus atšķiršanai nepieciešamais aberāciju apjoms ir loti atkarīgs no viḷnu frontes kartes orientācijas un simetrijas, kā arī aberāciju veidam, kam cilvēks dzìves laikā adaptējies.

30.08.2010. 